\title{
LACK OF FIRST-PASS METABOLISM OF ETHANOL AT BLOOD CONCENTRATIONS IN THE SOCIAL DRINKING RANGE
}

\author{
John G. Wagner
}

College of Pharmacy and Upjohn Center for Clinical Pharmacology, Medical Schoo1, The University of Michigan, Ann Arbor, MI 48109-0504

\author{
(Received in final form May 12, 1986)
}

\begin{abstract}
Summary
Previously published data are displayed in a new manner and show that there is complete systemic availability of oral doses of 23$47 \mathrm{~g}$ of ethanol $(0.35-0.75 \mathrm{~g} / \mathrm{kg}$ or $30-60 \mathrm{ml}$ of $95 \%$ ethanol) in man when administered in the fasting state relative to an intravenous infusion of the same doses administered over a 2-hr period. A previous report by other authors that oral ethanol $(0.75 \mathrm{~g} / \mathrm{kg})$ in man had a mean systemic availability of only $29 \%$ is explained by the fact that the subjects were fed one hour prior to administration of the alcohol and that the intravenous dose was infused over only a 20 minute period.
\end{abstract}

In a recent article in this journal Julkunen et al (1) reported that three male nonalcoholics administered ethanol $(0.15 \mathrm{~g} / \mathrm{kg})$ orally one hour after a standard morning meal gave a mean area under the blood ethanol concentration-time curve (AUC) of $1.43 \pm 0.65 \mathrm{mmol} /(1 \mathrm{x} \mathrm{hr})$ versus a mean AUC of $4.89 \pm 0.4 \mathrm{mmol} /(1 \mathrm{x} \mathrm{hr})$ when the same dose was infused intravenously over a 20 minute period - which gives an absolute systemic availability of only $29.2 \%$.

In this article some of the results obtained in previous studies (2-6) are presented in a new manner in order to show, with a larger number of subjects than used by Julkunen et al (1), that under different conditions than they used, administration of ethanol orally at dose levels in the social drinking range yielded AUC values essentially identical and sometimes even larger than those observed when the same doses were administered via intravenous infusion over a 2-hr period. When Michael is-Menten elimination kinetics are operative the rate of presentation of metabolizable compound to liver enzymes is a major determinant of systemic availability (7-15). Theory indicates that when the rate of presentation is equal to or exceeds the maximal rate of metabolism, $V_{m}$, then systemic availability is, complete. We (2) have estimated the average $V_{m}$ of ethanol to be $8.7 \mathrm{~g} / \mathrm{hr}\left(V_{\mathrm{m}}=75 \mu \mathrm{M} / 1 / \mathrm{min}\right.$ based on a $V_{d}$ of 421 ) in normal nonalcoholic male volunteers. Hence oral input rates equal to or greater than $8.7 \mathrm{~g} / \mathrm{hr}$ should theoretically lead to complete systemic bioavailability. In addition, estimations made since publication of the original articles $(2-6)$ indicate that the metabolic or intrinsic clearance of ethanol averages about $1.5 \mathrm{~L} / \mathrm{min}$ in man, which is the average value usually quoted for liver blood flow in man. This means that, using these average values, the bioavailability of ethanol is 0.5 or $50 \%$ as the dose rate approaches zero and the bioavailability increases gradually until the bioavailability becomes 1.0 or $100 \%$ when the dose rate reaches $8.7 \mathrm{~g} / \mathrm{hr}$ (13). These predictions are based on the assumption that the input rate is the same for intravenous and oral dosing. 


\section{Methods}

Human studies: Details of the studies have been reported in previous articles (2-6). Study $A(3)$ : Six nonalcoholic male volunteers each were infused intravenously with $720 \mathrm{ml}$ of $8 \% \mathrm{~V} / \mathrm{V}$ ethanol in physiological saline over a 2-hr period; this provided a dose of $46 \mathrm{~g}$ (1 mole) absolute ethanol, and since the panel had a mean body weight of $80.1 \mathrm{~kg}$, the mean dose was $0.574 \mathrm{~g} / \mathrm{kg}$. A seventh person (JW) was infused twice - once with same dose as above and, on the second occasion, with one-half the dose with respect to both the alcohol and volume infused over the 2-hr period. Capillary blood alcohol concentrations were measured by a head-space GLC method (5) at 29 sampling times over a 0-7.75 hr period after each dose. Study B $(2,4)$ : Eight nonalcoholic male volunteers, weighing $74.6 \mathrm{~kg}$ (range $66-89 \mathrm{~kg}$ ), were each administered doses of $15,30,45$ and $60 \mathrm{ml}$ of $95 \%$ alcohol in orange juice (total volume $150 \mathrm{ml}$ ) after a $10 \mathrm{hr}$ fast in crossover fashion at 7 -week intervals. Only the $60 \mathrm{~m} 1$ (approx. 1 mole or $0.608 \mathrm{~g} / \mathrm{kg}$ ) data are used in this article. A ninth person (JW) received $23.6 \mathrm{~g}$ (approx $0.5 \mathrm{~mole}$ or $0.372 \mathrm{~g} / \mathrm{kg}$ ) oral doses on two occasions and one $47.2 \mathrm{~g}$ (approx 1 mole or $0.743 \mathrm{~g} / \mathrm{kg}$ ) oral dose al1 under fasting conditions (6). After $60 \mathrm{ml}$ doses the capillary blood ethanol concentrations were measured by a head-space GLC method (5) at 38 sampling times over a $7-h r$ period, and after the lower doses given to JW, the capillary blood ethanol concentrations were measured by a GLC method (6) at 15 sampling times.

\section{AUC's were estimated by the trapezoidal rule.}

\section{Results and Discussion}

Figure 1 is a plot of the mean capillary blood ethanol concentrations versus time for the six subjects given 1 mole of ethanol by intravenous infusion over a 2-hr period in Study $A$ and for the eight subjects given slightly less than 1 mole $(45.4 \mathrm{~g})$ orally in the fasting state. The AUC for the mean P0 curve is $2.610(\mathrm{mg} / \mathrm{ml}) \times \mathrm{hr}[56.7(\mathrm{mmol} / 1) \times \mathrm{hr}]$, which is the same as the mean AUC of $2.611(\mathrm{mg} / \mathrm{ml}) \times \mathrm{hr}$ of the 8 individual subject AUC's. The AUC for the mean IV curve is $2.284(\mathrm{mg} / \mathrm{ml}) \times \mathrm{hr}[49.6(\mathrm{mmol} / \mathrm{l}) \times \mathrm{hr}]$, which is essentially the same as the mean AUC of $2.279(\mathrm{mg} / \mathrm{ml}) \times \mathrm{hr}$ of the 6 individual subject AUC's. Thus, the absolute systemic availability estimated from the mean AUC's of individual subjects if $\frac{2.617}{2.279} \times \frac{46}{45.4} \times 100=116 \%$. This is valid since although the AUC-dose plot when Michaelis-Menten elimination kinetics are operative, is parabolic $(8,21)$, it is reasonable to make a linear dose correction when the doses and AUC's are very close together. It should be noted in Figure 1 that the downslope elimination phases are essentially superimposable, particularly from 3.5 to 8 hours. The fact that the systemic availability exceeds $100 \%$ may be explained by the fact that the input rate in the fasted subjects was considerably more rapid when the ethanol was given orally (peak concentration at $1-h r$ ) than when the ethanol was infused I $V$. (peak concentration at 2-hr) and the operation of Michael is-Menten elimination kinetics $(8,12,18,20,21)$. In addition, the slope of the pseudo-linear el imination phase in the $3.5-5.5 \mathrm{hr}$ period estimated from the PO mean data in Figure 1 is $0.166 \mathrm{mg} /(\mathrm{ml} \times \mathrm{hr})[60.0 \mu \mathrm{mol} / 1 / \mathrm{min}]$, and that estimated from the IV mean data is $0.162 \mathrm{mg} /(\mathrm{ml} \times \mathrm{hr})[58.6 \mu \mathrm{mol} / 1 / \mathrm{min}]$ - which are essentially identical to the $58 \mu \mathrm{mol} / 1 / \mathrm{min}$ reported by Keiding et al (16) for ethanol elimination in nonalcoholics at a $10 \mathrm{mmol} / 1$ concentration.

The effect of input rate on AUC for ethanol was simulated by using a $V_{m}^{\prime}=$ $0.202 \mathrm{mg} /(\mathrm{ml} \times \mathrm{hr})$ and a $\mathrm{K}_{\mathrm{m}}$ value of $0.082 \mathrm{mg} / \mathrm{ml}$, reported formeriy as a result of fitting data from Study $B(4)$, and the model equation 1 with the Runge-Kutta numerical integration method and an Apple microcomputer, where $C$ is the simulated concentration, $V$ is the volume of distribution (taken as 401 ), Ro is 


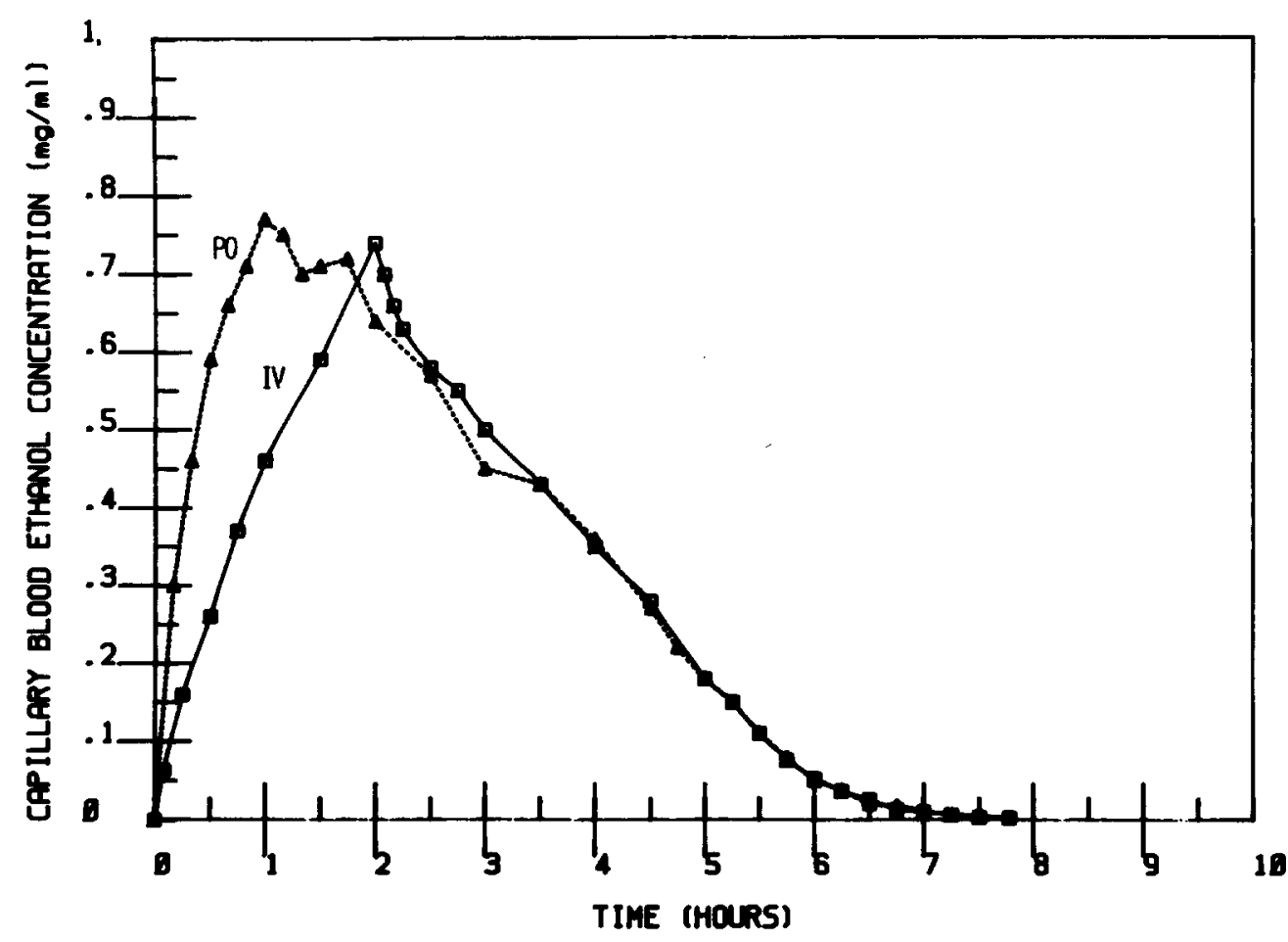

FIG. 1

Comparison of mean capillary blood ethanol concentrations in nonalcoholic male subjects.

Key: Study B: 8 subjects given $45.4 \mathrm{~g}$ ethanol in fasting state oral7y.

a study A: 6 subjects given $46 \mathrm{~g}$ ethanol by I.V. infusion over 2 hours.

$$
\frac{d C}{d t}=\frac{R_{0}}{V}-\frac{V_{m}^{\prime} C}{K_{m}+C}
$$

the mass/time infusion rate, and $R_{0} / V$ is the mass/(volume $x$ time) input rate. $R_{0}$ was made operative over times ( $T$ ) from 0 (bolus administration) to 2 hours.

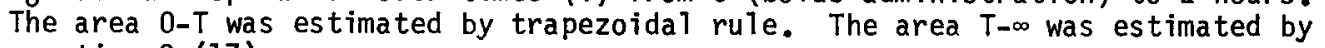
equation 2 (17),

$$
\text { AUC } T-\infty=\frac{C_{T}}{V_{m}^{T}}\left[\frac{C_{T}}{2}+k_{m}\right]
$$

where $C_{T}$ is the concentration at the end of the infusion at $T$ hours. The two areas were than added to obtain AUC $0-\infty$. The table below given the results of simulations where the dose was $10.5 \mathrm{~g}$ ethanol $(0.15 \mathrm{~g} / \mathrm{kg})$ as in the study of Julkunen et al (1).

The data in Table 1 indicate that the infusion time of 20 minutes used by Julkunen et al (1) would make their' $I: V$. AUC relatively higher than the infusion time of hours used in our Study $A_{\text {。 }}$. We have shown that both liquid (18, 19) and solid (20) foods reduce ethanol absorption rate and reduce ethanol AUcis. 


\section{TABLE 1}

Auc's Obtained In The Input Rate Simulations

\begin{tabular}{|c|c|c|c|c|c|}
\hline \multirow{2}{*}{$\begin{array}{c}\begin{array}{c}\text { Infusion } \\
\text { Time } T \text { (Minutes) }\end{array} \\
\end{array}$} & \multirow{2}{*}[\begin{array}{c}{R_{0}/V}\\
{[\frac{mg}{m}\times}\end{array}]{} & \multicolumn{3}{|c|}{ AUC $\left[\frac{\mathrm{mg}}{\mathrm{ml}} \times \mathrm{hr}\right]$} & \\
\hline & & $0-T$ & $T-\infty$ & $0-\infty$ & \\
\hline 0 & & --- & -- & 0.2769 & $1=$ \\
\hline 3 & 5.25 & 0.00642 & 0.26589 & 0.2723 & 吕. \\
\hline 6 & 2.265 & 0.01263 & 0.25759 & 0.2702 & $\overrightarrow{0}$ \\
\hline 9 & 1.75 & 0.01862 & 0.24941 & 0.2680 & $\frac{2}{3} \frac{0}{2}$ \\
\hline 12 & 1.3125 & 0.02439 & 0.23976 & 0.2642 & . \\
\hline 15 & 1.05 & 0.02994 & 0.23186 & 0.2618 & ตี \\
\hline 18 & 0.875 & 0.03527 & 0.22408 & 0.2594 & 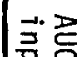 \\
\hline 20 & 0.78758 & 0.03873 & 0.21795 & 0.2567 & है \\
\hline 40 & 0.39379 & 0.06856 & 0.17036 & 0.2389 & 2 \\
\hline 60 & 0.2625 & 0.0908 & 0.13299 & 0.2238 & 8 \\
\hline 120 & 0.13125 & 0.12335 & 0.06257 & 0.1859 & $\forall$ \\
\hline
\end{tabular}

The breakfast used by Julkunen et al (1) was essentially the same as the breakfast used as treatment $C$ by Lin et al (20). When the oral ethanol dose $(45 \mathrm{ml}$ of $95 \%$ ethanol) was given with such a breakfast the AUC was reduced to 79.7 $(\mathrm{mg} / \mathrm{ml}) \times \mathrm{hr}$ compared with $213(\mathrm{mg} / \mathrm{ml}) \times \mathrm{hr}$ in the same subjects under fasting conditions. Since such a fatty breakfast empties slowly from the stomach it is most probable that it slowed absorption of ethanol even though the ethanol was taken 1 hour after the breakfast in the study of Julkunen et al (1). Such a slower rate of absorption would result in the AUC being lower than that obtained for fasting conditions.

Figure 2 shows results obtained in subject JW. AUC is plotted versus $\mathrm{g} / \mathrm{kg}$ dose for two'I:V. infusion doses and 4 oral treatments including three different doses. The least squares parabola forced through the origin, based on a 116 points is the line plotted in the Figure and conforms to theory of Michaelis-Menten kinetics (21). This plot strongly supports the lack of a first-pass effect.

Figure 3 shows a plot of results obtained in Studies A and B. Again AUC is plotted versus $\mathrm{g} / \mathrm{kg}$ dose. There are 32 points corresponding to 4 oral doses in each of 8 subjects and 6 points corresponding to one' I.V. dose in 6 subjects. Again the least squares parabola forced through the origin based on all 38 points is the line drawn through the points. Again, this plot strongly supports the lack of a first-pass effect.

The parabolic relationships shown in Figures 2 and 3 indicate that the lower the dose of ethanol the lower the AUC/dose ratio. Thus, another reason why the AUC's reported by Julkunen et al (1) are relatively much samiler than those reported in this article is the Tow dose they used relative to those we used.

The results we obtained in 3 subjects (JW, RS and PW) who received both intravenous and oral doses at different times are summarized in Table II. 


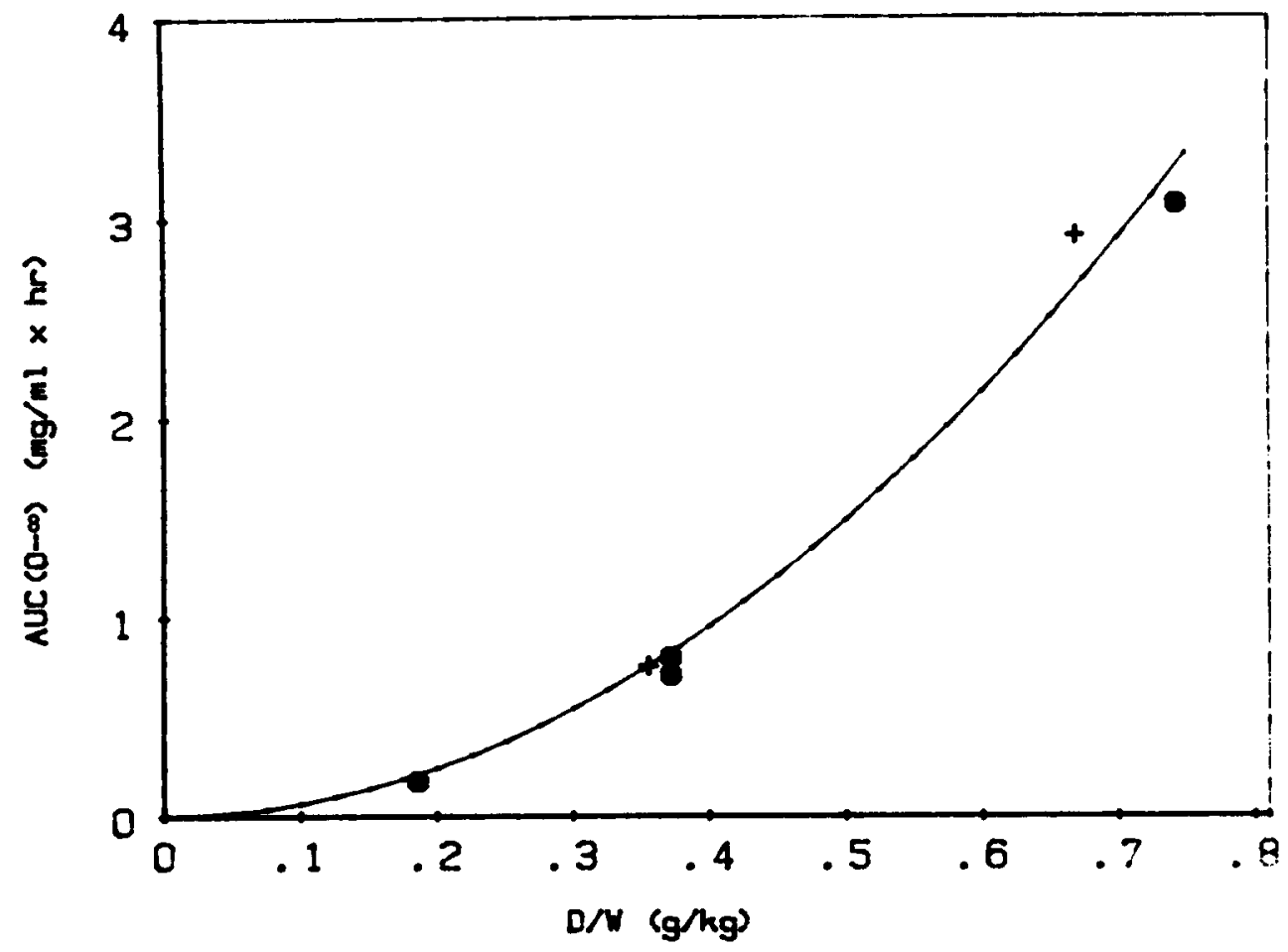

FIG. 2

Plot of AUC of blood ethanol concentrations versus $\mathrm{g} / \mathrm{kg}$ dose of ethanol in nonalcoholic subject JW.

Key: - Study B: 4 oral doses under fasting conditions. + Study A: 2'I.V. infusion doses given over 2 hours.

Curve drawn through the points is the least squares parabola forced through the origin.

The data obtained in rats by Julkunen et al (1) support our results in man. They reported a mean AUC of 8.71 (mmoT/1) $\times \mathrm{hr}$ when ethanol was infused into the portal vein versus $7.94($ mmol/1) $\times$ hr when ethanol was administered intravenously. These data indicate no first-pass metabolism of ethanol in rats. However, when they administered the ethanol by intragastric intubation the mean AUC decreased to $1.74(\operatorname{mmol} / 1) \times \mathrm{hr}$. They appeared to explain this by alcohol dehydrogenase activity in the stomach. However this author knows of no evidence that ethanol is either metabolized by an enzyme nor chemicaliy degraded in the stomach or intestine of man or the rat.

Dedrick and Forrester (22) stated: "approaching the limit of total extraction [of ethanol] by the liver the rate of oxidation [of ethanol] becomes dominated by hepatic blood flow and insensitive to the local enzyme kinetics." This partly explains our observations of lack of a first-pass effect at intermediate doses of ethanol. Keiding et al (16) reported a pseudo-linear decline of blood ethanol concentrations of $83, \frac{1}{\mu m o} 1 / 1 / \mathrm{min}$ in alcoholics following very high alcohol doses and initial ethanol concentrations of 40-80 $\mu \mathrm{mol} / 1$ (2-4 $\mathrm{mg} / \mathrm{ml}$ ), while nonalcoholics showed declines of $58 \mu \mathrm{mole} / 1 / \mathrm{min}$ for initial con- 
centrations of $10 \mathrm{mmol} / 1$. As stated formerly the slopes of 60.0 and 58.6 $\mu \mathrm{mol} / 1 / \mathrm{min}$ estimated from the PO and IV data, respectively, in Figure 1 are essentially identical to the nonalcoholic value reported by Keiding et al (16).

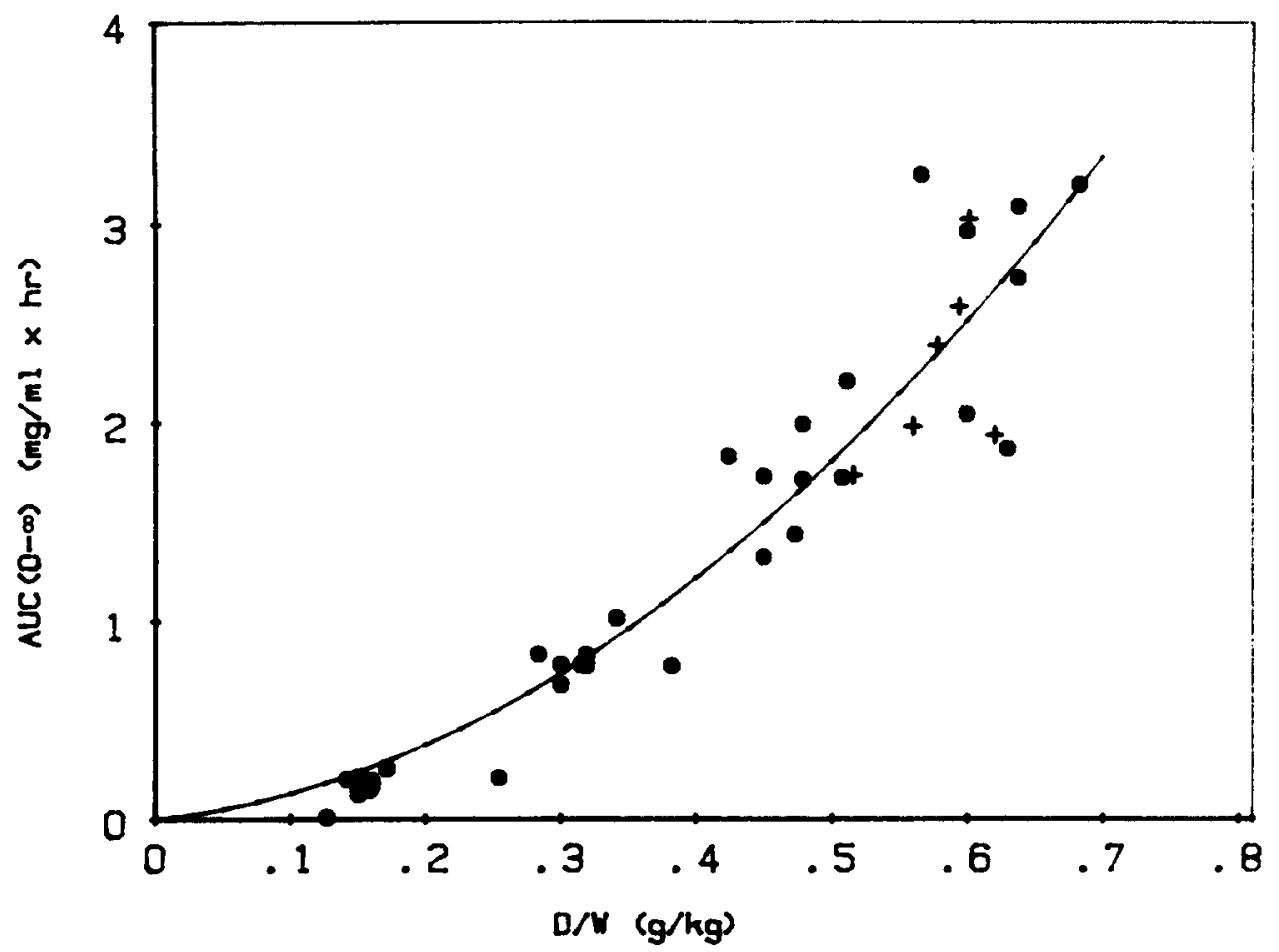

FIG. 3

Plot of AUC of blood ethanol concentrations versus $\mathrm{g} / \mathrm{kg}$ dose of ethanol. Key: - Study B: 4 different oral doses under fasting conditions in 8 nonalcoholic male subjects.

+ Study A: $46 \mathrm{~g}$ ethanol given in a volume of $720 \mathrm{ml}$ by I.V. infusion over 2 hours.

Julkunen et al (1) stated: "The magnitude of this FPM [first-pass metabolism] determines the bioavailability of alcohol and thus its potential toxicity. Prolonged alcohol abuse, by damaging the 'protective' gastrointestinal barrier, increases the bioavailability of ethanol, thereby enhancing the central nervous system effects and the various toxic manifestations of ethanol in the alcoholic." This author believes this is a misleading and unfounded statement. Results reported in this article indicate that there is no first-pass effect when ethanol is administered in the social drinking dose range of 23-47 $g$ of ehtanol (30-60 $\mathrm{ml}$ of $95 \%$ alcohol). There can be no increased bioavailability of alcohol in alcoholics since nonalcoholics exhibit $100 \%$ or even greater systemic bioavailability. Bioavailability in excess of $100 \%$ is explained in that the intravenous input rate is significantly less than the input rate resulting from oral administration. 


\section{TABLE II}

Data Indicating Lack of First-Pass Effect in Three Subjects When Subjects Fasted Prior to Oral Administration

\begin{tabular}{|c|c|c|c|c|c|c|c|}
\hline Subject & $\begin{array}{c}\text { Body } \\
\text { Weight } \\
(\mathrm{kg}) \\
\end{array}$ & Route & $\begin{array}{c}\text { Dose } \\
\text { (Grams) }\end{array}$ & {$\left[\begin{array}{l}\mathrm{mg} \\
\mathrm{ml}\end{array}\right.$} & $\begin{array}{c}\text { Systemic } \\
\text { Bioavailability } \\
\end{array}$ & {$\left[\begin{array}{c}v_{\mathrm{m}}^{\prime} \\
\mathrm{mg} \\
\mathrm{m} ! \mathrm{hr}\end{array}\right.$} & $\begin{array}{c}K_{m} \\
(\mathrm{mg} / \mathrm{ml}) \\
\end{array}$ \\
\hline \multirow[t]{5}{*}{ JW } & 66.2 & $I: V$. & 23.519 & 0.8385 & - & 0.161 & 0.0208 \\
\hline & 63.5 & P:O. & 23.6 & 0.8025 & 1.04 & - & -- \\
\hline & 63.5 & $P: 0$ & 23.6 & 0.7093 & 1.18 & - & - \\
\hline & 66.2 & I.V. & 44.327 & 2.917 & -- & 0.192 & 0.0335 \\
\hline & 63.5 & $P: 0$. & 47.2 & 3.072 & 0.90 & - & $\cdots$ \\
\hline \multirow[t]{2}{*}{ RS } & 75.0 & $I: V$. & 46.545 & 1.941 & - & 0.192 & 0.0302 \\
\hline & 75.0 & $P: 0$. & 45.00 & 2.968 & 1.58 & - & - \\
\hline \multirow[t]{4}{*}{ PW } & 79.6 & I.V. & 47.322 & 2.586 & - & 0.238 & 0.0762 \\
\hline & 79.5 & $P: O$ & 45.00 & 3.249 & 1.31 & - & - \\
\hline & \multicolumn{7}{|c|}{ Mean $\quad 1.20$} \\
\hline & \multicolumn{7}{|c|}{ C.V. (\%) 21.7} \\
\hline
\end{tabular}

If anything is life saving in man with respect to ethanol it is the effect of ethanol on stomach emptying. The larger the dose of ethanol the slower the stomach empties; this coupled with the operation of Michael isMenten el imination kinetics results in lower AUC's. This effect probably saves the lives of those foolish persons who ingest large amounts of ethanol all at once(4). The other very important factor is the type and amount of food taken with the alcohol. The more food one eats the slower the rate of absorption of the ethanol (most probably because of food slowing the rate of stomach emptying), the lower the AUC for a given dose and the less the state of inebriation $(6,18,20)$. This author and his co-investigator (PKW) have had many test doses of ethanol accompanied by measurement of alcohol blood concentrations and can attest to the profound effect of food on blood ethanol concentrations and the sensory effects of alcohol.

\section{References}

1) R. J.'K. JULKUNEN, 'C. DI PADOVA and 'C. 'S. LIEBER, Life Sci. 37:567-573 (1985)。

2) 'J.' G. WAGNER, 'P. K. WILKINSON, A.' J. SEDMAN, D. 'R。 KAY and 'D.' J。 WEIDLER, J. Pharm. Sci. 65:152-154 (1976).

3) P. K. WILKINSON, A. J. SEDMAN, E. SAKMAR, R.'H. EARHART, D. J. WEIDLER and J. G. WAGNER, Ci in. Pharmacol. Ther. 19:213-223 (1976).

4) P. K. WILKINSON, A. J. SEDMAN, E. SAKMAR, D. R. KAY and J. G. WAGNER, J. Pharmacokin. Biopharm. 5:207-224 (1977).

5) P. K. WILKINSON, J. G. WAGNER and A.'J. SEDMAN, Anal. Chem, 47:1506-1510 (1975).

6) J.G. WAGNER and J. A. PATEL, Res. Com. Chem。Path. Pharmaco1. 4:61-76 (1972).

7) M. ROWLAND, Dosage Form Design and Bioavailability, p. 181, Lea \& Febiger, Philadelphia, PA (1973).

8) J. G. WAGNER, J. Pharmacokin. Biopharm. 1:103-121 (1973).

9) J. G. WAGNER, Drug Int. Clin. Pharm. 13:47 (1979). 
10) J. G. WAGNER, Clin. Pharmaco1。Ther, 36:1-4 (1984).

11) J. G. WAGNER, J。C. SACKELLARES, D. D. DONOFRIO and S. BERENT, Ther. Drug Monitoring 6:277-283 (1984).

12) J. G。 WAGNER, Clin. Pharmacol. Ther, 37:481-487 (1985).

13) J. G. WAGNER, G. J. SZPUNAR and J. J. FERRY, J. Pharmacokin. Biopharm. 13:73-92 (1985).

14) J. G. WAGNER, E. J. ANTAL, A. T. ELVIN, W. R. GILLESPIE, E. A. PRATT and K. S. ALBERT, Biopharm. Drug Dispos. 6:347-343 (1985).

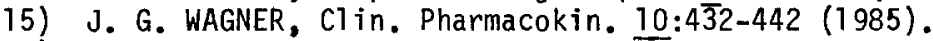

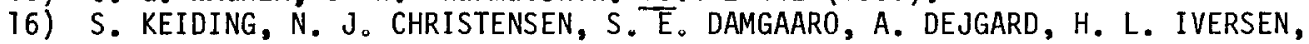
A. JACOBSEN, S. JOHANSEN, F. LUNDQUIST, E. RUBINSTEIN and K. WINKLER, Biochem. Pharmacol. 3c:3097-3102 (1983).

17) J.G. WAGNER, Fundamentals of Clinical Pharmacokinetics, p. 255, Drug Inteli igence Publications, Hamilton, IL (1975).

18) A. J. SEDMAN, P. K. WILKINSON, E. SAKMAR, D. J. WEIDLER and J. G. WAGNER, J. Studies on Aicohol 37:1797-1214 (1976).

19) P. K. WILKINSON, A. J. SEDMAN, E. SAKMAR, 'Yo- J. LIN and J. G. WAGNER, J. Pharmacokin. Biopharm. 5:41-52 (1977).

20) Y. - J. LIN, D. J. WEIDLER, D. C. GARG and J. G. WAGNER, Res. Com. Chem. Patho. Pharmaco1. 13: 713-722 (1976).

21) J. J. FERRY and J. G. WAGNER, Biopharm. Drug Dispos. 6:335-339 (1985).

22) R. L. DEDRICK and D. D. FORESTER, Biochem. Pharmaco1. 22:1133-1140 (1973). 